\title{
BETWEEN AMATEUR ASTROLOGY AND ERUDITE GIMMICK: A RE-EXAMINATION OF TRIMALCHIO'S HOROSCOPE (PETR. SAT. 39)
}

\begin{abstract}
Summary: I will present a new interpretation of Trimalchio's "learned" horoscope at Petr. Sat. 39. The aim is to point out that Trimalchio neither entirely comes out as amateur astrologer nor is his horoscope fully based on astrological treatises of his times. On the contrary, Trimalchio undertakes a widely unlearned methodological approach, recycles however astrological material and mixes this up with erudite puns at the internal recipients (the scholastici Agamemnon, Encolpius and co. who attend the dinner, yet fail to be worthy their profession).
\end{abstract}

Key words: Petronius, Satyrica, astrology, horoscope, erudition, Manilius

fata quoque et vitas hominum suspendit ab astris,

natura $[\ldots]$ quae summas operum partes, quae lucis honorem, quae famam assererent, quae numquam fessa volarent.

(Manil. 3. 47-60)

nature also made men's lives and destinies dependent on the stars, so that in their unwearied revolution they should claim charge of the human activity, the boon of life, and fame. ${ }^{1}$

\section{INTRODUCTION}

In the only continuously preserved episode of Petronius' Satyrica, the Cena Trimalchionis, the host Trimalchio makes clear to his guests that he does not do anything

${ }^{1}$ All passages from the Cena have been taken from the edition by K. MÜLLER: Petronivs, Satyricon Reliqviae. Munich - Leipzig 2003; all translations are taken from J. P. SULLIVAN: Petronius, The Satyricon. London 2011; all passages from Manilius are from the edition by G. P. GoOLD: Manilivs, Astronomica. Leipzig 1985 and the translation by G. P. GoolD: Manilius, Astronomica. Cambridge, MA - London 1977.

I wish to thank Ian Sinclair for correcting my English. I am of course solely responsible for all the remaining deficiencies. 
without a reason (nihil sine ratione facio, Sat. 39. 14). This is exemplified in a crucial passage where, after having his zodiac dish brought in (Sat. 35), he attempts to display his erudition and impress his purportedly learned audience.

This 'learned' horoscope (Sat. 39) has long remained one of the most puzzling episodes of the Cena. ${ }^{2}$ Several scholars have tried to decode the seemingly cryptic meaning of this passage, without enduring success. ${ }^{3}$ Perhaps the most significant interpretations are those offered by the Dutch scholar Jacques de Vreese (1927) and the Swedish researcher Sven Eriksson (1956), who offer two opposing interpretations of Trimalchio's expositions. ${ }^{4}$ While de Vreese pursues the hypothesis that Trimalchio's horoscope is based fully on astrological treatises from antiquity, such as Manilius' Astronomica, Firmicus Maternus' Mathesis, and the Catalogus Codicum Astrologorum Graecorum, Eriksson reads the host's approach as dilettante and non-scientific. Their contributions led to several further articles varying in their respective agreement or disagreement with one or other of these analyses.

Here, I offer a new interpretation of Trimalchio's horoscope (Sat. 39) that can be situated between these two apparently conflicting positions. Central to my undertaking is the elaboration of a clear narratological distinction between author, narrator, and protagonists. These distinctions, which have not at all or only partially been undertaken in extant contributions, will enable me to evaluate the Petronian passage in a markedly different manner to other readings. ${ }^{6}$ I begin from a structuralist approach in order to emphasise the widely neglected narrative frame of the horoscope. The

\footnotetext{
${ }^{2}$ In my contribution I will use the term 'horoscope' to denote Trimalchio's explanations on the influence of star signs on people born under them. Cf. DNP V s.v. Horoskop.

${ }^{3}$ On Petronian scholarship on this passage up to the early twentieth century, cf. DE VREESE, J. G. W. M.: Petron 39 und die Astrologie. Amsterdam 1927, at 1-4.

${ }^{4}$ ERIKSSON, S.: Wochentagsgötter, Mond und Tierkreis. Laienastrologie in der römischen Kaiserzeit. Stockholm 1956.

${ }^{5}$ Cf. BARTAluCCI, A.: Gli arietilli in Petronio. Sat. 39.5. SCO 16 (1967) 281-285; BorghinI, A.: A proposito dello zodiaco petroniano. Aufidus 2 (1987) 63-85; CAIAZZA, I. - LuCARINI, C. M.: Per l'esegesi di Petr. Satyr. 39. MD 57 (2006) 237-240; KORENJAK, M.: In piscibus obsonatores et rhetores. Petr. 39.13'. PCPhS 52 (2006) 134-138; KeYER, D.: In Virgine mulieres, fugitivi et compediti (Petr. Sat. 39. 9). Hyperboreus 16/17 (2011-2012) 121-130, KEYER, D.: Trimalchio's Astrology. Naïve Superstitions or Intentional Jokes? (Petr. Sat. 35. 1-5; 39. 5-12). Hyperboreus 18 (2012) 264-94, as well as the commentaries by SMith, M. S.: Petronii Arbitrii Cena Trimalchionis. Oxford 1975; SchMELING, G. L.: A Commentary on the Satyrica of Petronius. Oxford 2011; and GianotTI, G. F.: La Cena di Trimalchione. Dal Satyricon di Petronio. Rome 2013.

${ }^{6}$ There are several ways to distinguish between the opinion of Encolpius the autodiegetic narrator and of his former self, i.e. the protagonist's. One example should be enough to highlight the fact that Encolpius the narrator must be treated separately from the protagonist: The narrator comments on his previous behaviour if he disagrees with it, cf. for instance the use of etiam in nec non ego quoque ebrius <et> qui etiam pictum timueram canem, dum natanti opem fero, in eundem gurgitem tractus sum (Sat. 72. 7). In turn, it is legitimate to assume that he is of the same opinion if he does not comment on it further.

On the necessary narratological distinction between these three instances in the Satyrica cf. most prominently BECK, R.: Some Observations on the Narrative Technique of Petronius. Phoenix 27 (1973) 42-61, BECK, R.: Encolpius at the cena. Phoenix 29 (1975) 270-283; CONTE, G. B.: The Hidden Author. An Interpretation of Petronius' Satyricon. Berkeley 1996; and WHITMARSH, T. - BARTSCH, S.: Narrative. In Whitmarsh, T. (ed.): The Cambridge Companion to the Greek and Roman Novel. Cambridge 2008, $237-260$, at $245-250$.
} 
framing passages I shall discuss contain signalling phrases for the interpretation of Trimalchio's astrological elaborations. Only by correctly evaluating these signals and unfolding the various layers that Petronius constructs can we decipher what message is being transmitted, and apposite justice to his complex oeuvre can be done.

I will neither follow Eriksson's hypothesis that Trimalchio entirely appears as an amateur astrologer nor de Vreese's suggestion that the host's horoscope is fully based on ancient astrological treatises. On the contrary, I will advance the claim that the host sometimes deliberately undertakes a widely unlearned approach and clearly recycles astrological material. Additionally, he articulates these statements with erudite jokes at the expense of his listeners. ${ }^{7}$ The scholastici Agamemnon, Encolpius and his companions, on the other hand, who attend the dinner, fail to accurately decode the meaning of these utterances. Trimalchio exposes and ridicules those who fail to understand his crafty approach, thus landing the joke firmly on the pretence of his guests' learnedness.

On an authorial level, the writer Petronius challenges the external reader by having Trimalchio present a partly fictitious, partly scientific astrological horoscope that in some instances shows traces of Manilian material. ${ }^{8}$ The author casts the external reader in the same role as does the dinner host of the text: both the reader of the Satyrica and Encolpius and his friends need to see through the multi-layered and thoughtful urbanitas Trimalchio attempts to exude. Furthermore, the author is able to ridicule Encolpius even further. The older, yet apparently not much wiser narrator relates these events without a semblance that he has understood the true meaning of Trimalchio's horoscope including the jokes at the expense of his past self.

\section{SOME THEORETICAL CONSIDERATIONS}

Before engaging in a hermeneutic analysis of the text, it is necessary to outline a backdrop to the overall discussion. Of particular importance is the supposed dichotomy

\footnotetext{
${ }^{7}$ It does not serve the purpose of this contribution to subclassify the astrological approach further into astronomico-physical, purely literally, and based on myths or other fables. Moreover, this task was meticulously undertaken by DE VREESE (n. 3), who has persuasively shown which of the approaches mentioned above led an astrologer to assigning certain character traits to each star sign in each instance. It will suffice to distinguish between what ancient readers may have interpreted as 'astrological' and 'non-astrological'. Although we do not have explicit comments on this, it can be reconstructed on the basis of actual astrological treatises - such as Manilius and Firmicus Maternus - by analysing their approach in greater detail.

${ }^{8}$ I agree with the assessment by RATTI, E.: L'età di Nerone e la storia di Roma nell'opera di Petronio. Bologna 1978, at 183, that the Satyrica must be treated with caution on various levels and layers, as subtle ambiguities and tricky plays were hidden by the protagonist Trimalchio and equally by the author Petronius: "È generalmente riconosciuto ormai che il romanzo non è lo scritto facile e incurante che sembra, che esso è un'opera piena di giochi segreti, di ambiguità volute, di doppi sensi burleschi. Per chiarirli tuttavia occorre cercare una spiegazione del romanzo che vada oltre il suo senso letterale." However, he goes too far when interpreting the entire Zodiac dish as a parody of Rome and a prediction of its future (137-80). It will suffice to quote the assessment by RUDICH, V.: Dissidence and Literature under Nero. The Price of Rhetoricization. London - New York 1997, at 329, that "leaps of fantasy [...] vitiate" Ratti's discussion.
} 
between 'popular' and 'scientific' astrology, and the possible hypertextual relationship between Petronius and the oeuvre of his alleged late Augustan or Tiberian predecessor. ${ }^{9}$

Korenjak $^{10}$ has appropriately drawn attention to the distinction between popular and scientific astrology, stating that "his [sc. Eriksson's] dichotomy of popular vs. scientific astrology may be a bit too strict, since the first certainly receives some inspiration from the second". I would argue that it is reasonable to go even further and suggest that the effect is rather reciprocal. In fact, Eriksson ${ }^{11}$ seems to admit that the approach of a scientific astrologer must be interpreted as popular at times. This is because, he argues, natural as well as invented constituent traits of the animal or human representing the star sign, as well as the underlying mythological narrations, seem to have had a wide public impact. For instance, the Ram's characteristic of bearing wool is given as the reason for the professions of people born under Aries. This can be discerned from the Roman astrologer Manilius (4. 124-39) who speaks extensively of professions connected to wool, such as the weaving and drapery trade, as existing under this sign. I therefore exercise caution and hesitation in applying a modern distinction between amateur and scientific astrology to ancient treatises. The need for such a reservation can be evidenced further in the work of Manilius, Firmicus Maternus, who composed his Matheseos libri VIII between 334 and $337 \mathrm{CE},{ }^{12}$ for he, and others, appear to have not observed this strict separation. Similarly, the limitations of this modern distinction must be borne in mind when dealing with ancient narratives that contain inserted astrological excursus or horoscopes, such as for instance Trimalchio's (Sat. 39).

In our case I suggest interpreting the Trimalchionian specimen as hypertext set against the background of Manilius' Astronomica, and following Gérard Genette, I shall denote the latter as the hypotext. Petronius the author alludes to the Astronomica by placing astrological concepts in the mouth of his protagonist. Trimalchio, in contrast to Petronius, has not read Manilius: he makes use only of popular and even technical discourse. Petronius, however, succeeds in setting up the connection between the host's horoscope and the Astronomica because his protagonist's observations, claims, and motifs resemble those of the first-century astrologer closely enough to be excavated on careful reading. In contrast, both the tone and the purpose of the erudite statements have been swapped: the scientific treatise was transformed into a freedman's gag for the purpose of entertainment of his guests. The manner in which hypoand hypertext are connected is playful, yet the boarder between imitation and transformation, ergo parody and pastiche, is frequently blurred.

${ }^{9}$ On the date of Manilius cf. VOLK, K.: Manilius and His Intellectual Background. Oxford - New York 2009, at 137-161; and GREEN, S. J.: Disclosure and Discretion in Roman Astrology. Manilius and His Augustan Contemporaries. Oxford 2014, at 11. In Genettean terminology it is more adequate to speak of 'hypertextuality' rather than 'intertextuality' in our case.

${ }^{10}$ KORENJAK (n. 5) 135 n. 6.

${ }^{11}$ ERIKSSON (n. 4) 43-45.

${ }^{12}$ On the date of Firmicus Maternus, cf. DNP IV s.v. Firmicus Maternus, Iulius. 


\section{THE NARRATIVE CONTEXT OF TRIMALCHIO'S HOROSCOPE}

Before presenting his horoscope, Trimalchio calls for his audience's attention. His guests should not underestimate him and his erudition, for his former patron took special care to ensure that he would be well educated, even when dining (oportet etiam inter cenandum philologiam nosse. patrono meo ossa bene quiescant, qui me hominem inter homines voluit esse, Sat. 39. 4). ${ }^{13}$ The host emphasises his request by quoting Virg. Aen. 2. 44 (sic notus Ulixes?), where Laocoon warns the Trojans to be careful not to get deceived by Ulysses' cunning. ${ }^{14}$ Trimalchio's call for caution when considering his actions is taken up again towards the end of his astrological explanations (nihil sine ratione facio, Sat. 39. 14) and, thus frames this section. Listeners are twice given an admonition, preceding and succeeding the host's astrological monologue.

Following up on his claim for erudition, Trimalchio triggers his astrological horoscope by referring to the zodiac dish he had brought in earlier during the Cena (Sat. 35). ${ }^{15}$ The horoscope must not be interpreted in strict relation to the dish as neither the dish itself nor the arrangements of the various meals on it have immediate influence on the expositions that follow. ${ }^{16}$ In fact, the freedman only needs to have this dish placed on the dinner table in order to have a good reason to initiate the demonstration of his astrological knowledge.

\section{THE DUODECIM DII}

Soon after his call for caution Trimalchio first allows an insight into his astrological knowledge:

${ }^{13}$ [']rogo, me putatis illa cena esse contentum, quam in theca repositorii videratis? "sic notus Ulixes?" quid ergo est? oportet etiam inter cenandum philologiam nosse. 4 patrono meo ossa bene quiescant, qui me hominem inter homines voluit esse. (Sat. 39. 3-4)

I ask you, do you think I'm just content with that course you saw in the bottom of the dish? "Is this like the Ulysses you know?" Well then, we've got to display some culture at out dinner. My patron - God rest his bones! - wanted me to hold up my head in any company.

On the expression inter cenandum philologiam nosse cf. also Plin. Ep. (1. 15. 3: quantum nos lusissemus risissemus studuissemus) with SMITH (n. 5) 88; on the interpretation of homo inter homines as "man of culture" cf. Sen. Apoc. 5. 4 with SchMELING (n. 5) 150. The phrase is taken up again by the freedman Hermeros at Sat. 57. 4-5 and by Trimalchio himself at Sat. 74. 13.

${ }^{14} \mathrm{Cf}$. SMith (n. 5) 88 and GiANOTTi (n. 5) 306: "Nel passo virgiliano Ulisse è evocato come figura negativa, noto per l'astuzia ingannatrice; qui invede Trimalchione si identifica con l'antico eroe in nome di presunta intelligenza".

${ }^{15}$ nam mihi nihil novi potest afferri, sicut ille fer [i]culus †ta mel† habuit praxim. (Sat. 39. 4)

There's nothing new to me, as that there dish proves.

${ }^{16}$ Even though the two may show similarities and connections, as CoLIN, J.: Encolpio e il piatto d'argento con lo Zodiaco (Petronio 35). RFIC 29 (1951) 97-144, at 109-144 has pointed out, the zodiac dish must be read against the background of astrological treatises such as Manilius'. Cf. COLIN 98f. against DE VREESE (n. 3) 14 and followed by KEYER: Trimalchio's Astrology (n. 5) 270f., and SCHMELING (n. 5) 152: “This exposition is both a display of T.'s knowledge of astrology (which is considerable and unlike his ignorance of mythology, which is an upper-class interest) and an ecphrasis on the pictures on the ferculum which was brought into the dining room at 35.1." 
caelus hic, in quo duodecim dii habitant, in totidem se figuras convertit (Sat. 39. 5)

Look now, these here heavens, as there are twelve gods living in 'em, changes into that many shapes.

The host starts by connecting the dish, which is divided into twelve parts along the twelve zodiac signs, with the twelve main gods, yet omits to list them. Petronius deliberately leaves the task of recalling Ennius (Ann. 240-241 Skutsch), who listed them in two hexameters, to his guests: Iuno, Vesta, Minerva, Ceres, Diana, Venus, Mars / Mercurius, Iovis, Neptunus, Vulcanus, Apollo. ${ }^{17}$ In ancient astrology these twelve gods were closely connected to the twelve zodiac signs as to each of the latter was allocated one of the former. This becomes apparent from Manilius (2. 439447): ${ }^{18}$

\author{
Lanigerum Pallas, Taurum Cytherea tuetur, \\ formosos Phoebus Geminos; Cyllenie, Cancrum, \\ Iuppiter, et cum matre deum regis ipse Leonem; \\ spicifera est Virgo Cereris fabricataque Libra \\ Vulcani; pugnax Mavorti Scorpios haeret; \\ venantem Diana virum, sed partis equinae, \\ atque angusta fovet Capricorni sidera Vesta; \\ e Iovis adverso Iunonis Aquarius astrum est \\ agnoscitque suos Neptunus in aethere Pisces.
}

Pallas is protected by the Ram, the Cytherean of the Bull, and Phoebus of the comely Twins; you, Mercury, rule the Crab and you, Jupiter, as well as the Mother of the Gods, the Lion; the Virgin with her sheaf belongs to Ceres, and the Balance to

bellicose Scorpion clings to Mars;

Vulcan who wrought it;

Diana cherishes the hunter, a man to be sure, but a horse in his other half,

and Vesta the cramped stars of Capricorn; opposite Jupiter Juno has the sign of Aquarius, and Neptune acknowledges the Fishes as his own for all that they are in heaven.

${ }^{17}$ Cf. Smith (n. 5) 89, Schmeling (n. 5) 152, and Gianotti (n. 5) 307. Neither Martianus Capella (1.42) nor Apuleius (de deo Socratis 2. 6. 23), who refer to the two verses from Ennius, nor Ennius himself connect the twelve gods to the twelve star signs; this tendency is only made apparent by Manilius.

${ }^{18}$ Cf. ERIKSSON (n. 4) 55: "Die zwölf Götter, auf die Trimalchio anspielt, sind die zwölf Götter des römischen Kalenders, die mit den zwölf Tierkreisbildern und den zwölf Monaten zusammengestellt waren. Sie treten z.B. in dem bekannten römischen Bauernkalender, Menologium rusticum, auf. (CIL I $1^{2}$ S.280ff.). In diesem liest man z.B. unter dem Monat Januar u.a. SOL / CAPRICORNO / TUTELA IUNIONIS. Die1se tutelae der Tierkreiszeichen müssen wie die Monatsnamen und die Tierkreiszeichen selbst allgemein bekannt gewesen sein." 
Due to the gods' impact on the very star they monitor and, concomitantly, on the people born under this sign, it is of importance to know not only the personal sign but also the god of tutela. ${ }^{19}$ This is, again, highlighted by Manilius $(2.434-438,448-$ 452).

\section{TRIMALCHIO’S (ASTROLOGICAL?) HOROSCOPE}

The freedman's horoscope will be compared to the respective sections in the Manilian treatise, thus evaluating how astrological the former is. Finally, an explanation for those claims, which seem not to follow scientific patterns, will be attempted: the joke is at the expense of the unexpected dinner guests, the scholastici around Agamemnon and Encolpius.

\section{Aries}

et modo fit aries. itaque quisquis nascitur illo signo, multa pecora habet, multum lanae, caput praeterea durum, frontem expudoratam, cornum acutum. plurimi hoc signo scolastici nascuntur et arietilli'. (Sat. 39. 5)

First it becomes the Ram. So whoever is born under that sign has lots of herds, a lot of wool, a hard head as well, a brassy front and a sharp horn. Most scholars are born under that sign, and most muttonheads as well.'

Not only is starting with aries attested in both Manilius (1.263: Aurato princeps Aries in vellere fulgens, 3. 278) and Firmicus Maternus (Math. 3. 1. 17-18), but, judging by what can be found in the two major Roman astrological treatises, Trimalchio also keeps all twelve signs in the correct order. ${ }^{20}$

The host's list of people, who are born under this sign, only partly follows astrological material as found in Manilius' treatise. The importance of wool for the sign of Aries is stressed multiple times in the latter (4. 124-139, 504-517): for instance, he speaks of vellera $(124,129)$ and lanas $(130)$, filo and telas $(131)$, as well as vestes (132). Moreover, it recalls the sign's designation as laniger (for instance 2. 405, 550), as frequently applied in the Astronomica. Similar professions connected to Aries such as the shepherd are implied in similes [...] artes (Manil. 4. 135). ${ }^{21}$

The hard head, brassy front, and sharp horn are only peripherally mentioned in Manilius $(4.506,509)$. The astrologer focusses on speaking of dubia in trepido praecordia pectore (4.138) and non contenta suo generabit pectora censu (4. 507), which are, in turn, omitted by Trimalchio. These traits are rather based on the actual animal's

\footnotetext{
${ }^{19}$ Even though Trimalchio does not explicitly state this piece of knowledge, it is implied at various stages of these explanations.

${ }^{20}$ DE VREESE (n. 3) 23f. rightly stresses that this is not as obvious as the modern reader may think.

${ }^{21}$ Already this example proves ERIKSSON (n. 4) 83 wrong, when he states that Petronius deliberately does not have Trimalchio follow Manilius' predictions regarding the people born under a certain star sign.
} 
qualities - the ram is known for its hard head, brassy front, and sharp horn -, which Trimalchio transfers to the people born under this sign. Nonetheless, it is important to note that, even if they are only marginally stated in Manilius, these characteristics make sense speaking in ancient astrological terms. As has been pointed out above, natural as well as invented constituent traits of the animal or human, which represents the star sign, seem to have had a pronounced impact on the people born according to Roman astrologers. Petronius' method, as has become apparent already at this point, is eclectic: he chooses to have his protagonist omit some major characteristics while sometimes stressing minor factors. Some of these resemble the respective Manilian verses closely enough to set the Astronomica up as hypotext for the horoscope in the Satyrica.

Listing the scholars (scholastici) under Aries seems to be a first surprise in Trimalchio's horoscope. ${ }^{22}$ Why does the dinner host put them under Aries and not under Pisces together with the rhetorici? Manilius does not at any point mention that scholastici or any profession close to them is connected to this star sign. The answer lies in the context of Trimalchio's horoscope: at his dinner not only his fellow freedmen but also the group of scholastici and rhetores, i.e. Agamemnon and his followers Encolpius, Ascyltos, and Giton, are present. ${ }^{23}$ By inserting this unexpected, and for the uninvited guests even unforeseeable, joke at them into his astrological explanations Trimalchio is able to amuse some of his guests while unmasking the learned ones. ${ }^{24}$ In fact, those who should identify some parts of the Trimalchionian horoscope as nonastrological based on their degree of erudition, fail to be worthy of their profession. ${ }^{25}$ On the contrary, the first person plural in laudamus urbanitatem mathematici (Sat. 39. 6) implies that Encolpius was among those who were entertained by Trimalchio's explanations. ${ }^{26}$ This also applies to 'sophos' universi clamamus et sublatis manibus

${ }^{22}$ SMITH (n. 5) 88 notes that this "detail is eccentric".

${ }^{23}$ In the Satyrica scholastici either means students (6. 1, OLD s.v. 2a), professors (10.6, OLD s.v. 2a), or erudite people in general (61. 4, also in Quint. 12.11. 16, OLD s.v. 2b). All of these different forms imply a certain degree of learning above average. I agree with KORENJAK (n. 5) 135, following DE VREESE (n. 3) 213, 227, 244 and ERIKSSON (n. 4) 56-8, that scholastici (39. 5) refers to Encolpius and Ascyltus and rhetores (39. 13) to Agamenon, and thus frame Trimalchio's horoscope by referring to members of this group of invited guests at the beginning and at the end of the passage.

${ }^{24}$ SMITH (n. 5) 88 has rightly observed this intention: "[the scholastici] are put here out of place so that Trimalchio can poke fun at his better-educated guests, Agamemnon and his friends". I disagree with ERIKSSON (n. 4) 56, who suggests that Trimalchio tries to honour his guests by allocating the first star sign to them. Throughout the horoscope it will become more and more apparent that Trimalchio is making fun of them rather than flattering them. KEYER: Trimalchio's Astrology (n. 5) 274-6 even interprets multa pecora and multum lanae as a further sign "of intentional humour" equating sheep with crowds of students.

${ }^{25}$ KEYER: Trimalchio's Astrology (n. 5) 274 rightly observes that “Trimalchio's cosmological lecture is rooted in some commonly widespread religious or astronomical notions of the time, even though oversimplified or distorted in his discourse" even though his overall conclusions flow in the opposite direction of those pursued in this contribution and even contradict his own observations. Cf., for instance, 294: "Of course, Trimalchio does show himself a complete ignoramus in astronomy - as well as in history and mythology."

${ }^{26}$ On mathematicus as astrologer cf. Sat. 76. 10-11 and 126. 3 as well as Tac. Hist. 1. 22. 
ad cameram iuramus Hipparchum Aratumque comparandos illi homines non fuisse (Sat. 40. 1): ${ }^{27}$ If Encolpius had understood that the joke was partly on him, he would most likely not have reacted in such an amused way. Similarly, if he had understood to which degree Trimalchio had actually presented an astrological exposition, he would not have been among those who respect the host far more than Aratus and Hipparchus. On an authorial level, the author Petronius steps in and ridicules the uninvited guests further: not only does he have Trimalchio expose their intellectual pretentions, but he also makes clear that the first-person narrator Encolpius has not grown any wiser than his younger self was at the time.

Lastly, the mention of the arietilli has posed major difficulties since the word is not attested anywhere else in extant Latin literature. Bartalucci ${ }^{28}$ interprets the word in a sexual or erotic meaning and Smith $^{29}$ suggests that "Trimalchio might be hinting that rhetoricians meet like charging rams, or possibly some obscene sense lies hidden" and is followed by Keyer ${ }^{30}$; Schmeling ${ }^{31}$ finally proposes a translation of scholastici et arietilli as "declamation buffs and their little rams (E. and Ascyltos? [...])". 32 Since the meaning of this word remains obscure, I shall not go further than to stress the likeliness of another joke at the expense of the erudite dinner guests, as suggested by Smith and Schmeling. It cannot be excluded that a subtle sexual connotation reinforces the joke at Encolpius and his friends, who engage in various sexual encounters throughout the Satyrica.

\section{Taurus}

laudamus urbanitatem mathematici; itaque adiecit: 'deinde totus caelus taurulus fit. itaque tunc calcitrosi nascuntur et bubulci et qui se ipsi pascunt. (Sat. 39. 6)

We applauded the wit of our astrologer and he went on: 'Then the whole heavens turns into the little old Bull. So bullheaded folk are born then, and cow-herds and those who find their own feed.

After his dinner guests applauded him, Trimalchio carries on with the second star sign, Taurus. ${ }^{33}$ The calcitrosi ('self-willed people') "are placed under Taurus because in representations of the zodiac Taurus faces backwards and appears to go unwillingly", 34

${ }^{27}$ On sublatis manibus as "a gesture of prayer, hence used as an extravagant expression of approval” cf. SMITH (n. 5) 92 with Cic. Acad. 2. 63, Fam. 7. 5. 2, and OLD s.v. manus 5b.

${ }^{28}$ BARTALUCCI (n. 5).

${ }^{29}$ SMITH (n. 5) 89.

${ }^{30}$ KEYER: In Virgine mulieres (n. 5) 128.

${ }^{31}$ SCHMELiNG (n. 5) $152 \mathrm{f}$.

${ }^{32}$ On the hapax legomenon arietillus cf. also ALESSIO, G.: Hapax legomena ed altre cruces in Petronio. Naples 1960-1961, here 20-22.

${ }^{33}$ The diminutive taurulus "is a hapax and likely indicates a common animal in colloquial speech" (SCHMELING [n. 5] 153).

${ }^{34}$ SMITH (n. 5) 90; cf. also SCHMELING (n. 5) 153. This is substantiated further by Manilius' first mention of this sign as aversum [...] Taurum (1.264). Later, he speaks of aversus venit in caelum (4. 521). 
the bubulci due to the close connection with the animal. ${ }^{35}$ Similarly, the expression qui se ipsi pascunt recalls Manilius' claim that Taurus aims for hard, self-sustaining work sua sponte (4. 140-151; esp.: summittit in astris / colla iugumque suis poscit cervicibus ipse, 4. 142f.).

Additionally, some of these qualities stand in rather striking opposition to some of the dinner guests' features. Agamemnon and his group of fellow uninvited friends do not se ipsi pascunt as they would never miss an opportunity to attend a free dinner. $^{36}$

\section{Gemini}

in geminis autem nascuntur bigae et boves et colei et qui utrosque parietes linunt. (Sat. 39.7)

Under the Heavenly Twins on the other hand - pairs-in-hand, yokes of oxen, people with big ballocks and people who do it both ways.

Gemini follows as the third sign. Due to the sign's shape of a pair of twins everything Trimalchio connects to it is grouped as two pieces, for instance the bigae.

However, there is one further joke, which lies hidden in the closing remark. "[C]ertainly qui utrosque parietes linunt should be taken here as referring euphemistically to those who are equally adept in homosexual or heterosexual relationships".37 This is also implied in Sullivan's (2011) translation. Not entirely by chance, some of those guests, who were mocked both under Aries and under Taurus, might be characterised as bisexual: Encolpius, Ascyltos, and Giton seem not to be afraid of engaging with men and women equally, as can be seen from the episodes with Quartilla and Oenothea, as well as the triangular relationship of the three male characters throughout the remainder of the Satyrica.

In sum, Petronius deviates from Manilius under Gemini, who speaks of the mitior aetas / per varios cantus modulataque vocibus ora (4.153f.) and a life in talent and leisure (4. 152-161, 525-529).

\section{Cancer}

in cancro ego natus sum. ideo multis pedibus sto, et in mari et in terra multa possideo; nam cancer et hoc et illoc quadrat. et ideo iam dudum nihil super illum posui, ne genesim meam premerem. (Sat. 39. 8)

I was born under the Crab, so I have a lot of legs to stand on and a lot of property on land and sea, because the Crab takes both in his stride. And that's why I put nothing over him earlier, so as not to upset my horoscope.

\footnotetext{
${ }^{35}$ This is, again, paralleled in Manilius: Taurus simplicibus dotabit rura colonis, 4. 140. Similarly, calcitrare, which is a typical characteristic of oxen, is used with regards to humans, too; cf. Act. Apost. 26. 14 and ERIKSSON (n. 4) 57.

${ }^{36}$ Cf. Sat. 3. 3; 5. 1 V. 5; 10. 2; 10. 6; 26. 7; 52.7.

${ }^{37}$ SMith (n. 5) 90. Cf. SCHMELING (n. 5) 153, who argues for a more neutral interpretation.
} 
Under Cancer Trimalchio's approach becomes even trickier with both the recipient's attention and astrological knowledge being put to the test even more than previously. He himself, the nouveau riche declares, was born under this sign, which explains why he made a fortune as a salesman on land and water. Yet, one might ask how likely it is that the former slave Trimalchio knows his date of birth and, thus, his star sign?

The reason why he claims to have been born under Cancer becomes apparent when one examines the astrological qualities of this sign: Cancer is under the tutela of Mercury, the protecting deity of merchants (Manil. 2. 240), and, in fact, those born under it engage in various different métiers, especially in trade on land and see (4. 162175; esp.: merce, 167; bona vendere, 169 ; commercia, 170; navigat 173 ; vendit, 174). Trimalchio, then, introduces himself as Mercury's personal protégé at various points during the Cena highlighting his proximity to the god of merchants (Sat. 29. 3-6, 76. $3-7,77.4)$.

However, Manilius elsewhere (for instance at 2. 230-233) explicitly deals with those signs that take part in both elements water and earth. While the astrologer recalls Capricorn and Aquarius, he does not by any means speak of Cancer at that point. This, however, stands in sharp contrast to Trimalchio's exegesis and displays the host's eclectic approach to astrological discourse. Trimalchio selects details, being well aware of what is astrologically consistent and deviates from astrological teachings. Yet he leaves it up to the internal recipient to decode which parts of his expositions are based on actual astrological knowledge and which are to be referred to as pseudoscientific fantasies. The fact that he would be able to produce an entirely skilful horoscope in line with the science of his times, if he aimed at achieving this, is evidenced, for instance, by his correct use of genesis, a technical term in astrology. ${ }^{38}$

\section{Leo}

in leone cataphagae nascuntur et imperiosi (Sat. 39.9)

Under Leo are born greedy and bossy people.

Protected by the king of gods Jupiter (Manil. 2. 441) Leo seems to cause greed (avi$d u s$, Manil. 4. 535), an insatiable hunger and an untameable desire for violence and murder (4. 176-188, 535-541). Petronius has Trimalchio extend the influence of Jupiter in his horoscope even further by having him add bossy (imperiosi) people to the voracious ones dealt with in detail already in Manilius. Yet, this stands in one line with what the earlier author may have implied by the connection of Leo and Jupiter.

${ }^{38}$ Cf. Juv. 14. 248, where the term is explicitly used in connection with astrologers (mathematicis). Cf. ERIKSSON (n. 4) 70f., who admits that Trimalchio occasionally clearly makes use of astrological terminology: "Quisquis nascitur illo signo ... praeterea ... plurimi hoc signo gibt deutlich die Terminologie der Astrologen wieder. Das Aufzählen multa pecora ... multum lanae usw. erinnert an die astrologischen Listen. Aber auch in der Fortsetzung, wo Trimalchio sich kürzer fasst, tauchen hin und wieder Ausdrücke auf, die klare Reminiszenzen an die Sprache der Astrologen sind: et quicunque aliquid expendunt (Libra) und - dieses will ich besonders unterstreichen - ne genesim meam premerem. Das letztere muss ein gewöhnlicher terminus technicus gewesen sein". 
However, if we compare Trimalchio's explanation of Leo to those of the previous signs, there one can sense an impression that the horoscope has lost at least some of its ambiguity and playful gimmick. Initially, the host's statements regarding Leo conform neatly to scientific discourse as evidenced in Manilius and seem not to add any further joke displaying Trimalchio's urbanitas. As with most instances, where passages seem overly simplified and plain compared to Trimalchio's otherwise witty jokes, the key to decode the hidden meaning lies in the setting of the episode. In this instance, Trimalchio, who is hosting an extravagant dinner for some of his fellow freedmen, has welcomed some further uninvited guests who have turned out to be scholastici, and confronts all of these with an entertaining horoscope. Due to their profession, a higher level of erudition could, ideally, be expected from the spontaneously-invited guests than from the regular, invited participants. Yet, as has been made clear already under previous signs (Aries, Taurus, Gemini), Trimalchio appears to enjoy challenging this notion by unmasking the lack of learning of the supposedly knowledgeable and academic guests. On these grounds, the suggestion is not farfetched to connect the greedy (cataphagae) under Leo with their opposite, i. e. those qui se ipsi pascunt (Sat. 39. 6), who were placed under Taurus, and read both expositions as a parody of the parasite guests. ${ }^{39}$

\section{Virgo}

in virgine mulierosi et fugitivi et compediti ${ }^{40}$ (Sat. 39. 10)

Under the Virgin, effeminates, runaways and candidates for the chaingang.

In order to understand why these three types of people are born under Virgo according to Trimalchio, a reader ought to make use of imagination, mythological knowledge, and astrological expertise.

The attributions of both mulierosi and fugitivi are based on the myth of Erigone, who, at the end of the Golden Age, fled from the world and was turned into a constellation of stars. $^{41}$ Manilius alludes to this myth at $4.189 \mathrm{f}$. and explicitly states it at 4. 542f. However, neither of these two characteristics of those born under Virgo is mentioned in the Astronomica. On the other hand, Trimalchio omits the studiosi, eloquent speakers and writers (Manil. 4. 191-199) and the character trait of timidity (4. 200f.).

\footnotetext{
${ }^{39}$ Already KORENJAK (n. 5) 135 n. 7 rightly pointed out the possible "hint at the voracity of the guests".

${ }^{40}$ I here follow Gronovius' emendation (mulierosi) as used in Müller's edition against the version mulieres found in the MSS, as this would be the only instance where the people born under the sign correspond one-to-one to the figure of the constellation.

${ }^{41}$ I disagree with KEYER: In Virgine mulieres (n. 5) 123f., who rejects the notion that this myth is underlying the host's claim as "Trimalchio's erudition in mythology - as well as in history and astronomy is grotesque". Keyer's assessment is highly subjective and open to interpretation. For Trimalchio as an erudite host see n. $50 \mathrm{f}$.
} 
The understanding of compediti requires thorough astrological knowledge: "Virgo stood near one of the knots (nodi) or cardinal points of the zodiac, and in pictorial representations the feet of Virgo appeared to be bound by this knot." ${ }^{42}$ Similarly to mulierosi and fugitivi, Manilius does not explicitly refer to compediti as born under Virgo; rather their characteristics are either implied by the sign itself or its representation. On these grounds, Trimalchio's explanations, despite not being clearly attested in the Astronomica and in spite of its eclectic method, do not deviate from the scientific approach of the times Manilius applied.

Due to the fragmentary state of the Satyrica it would be speculative to read $f u$ gitivi as a further joke at the expense of the uninvited guests. ${ }^{43}$

\section{Libra}

Trimalchio's discussions of Libra and Scorpio seem to be quite straightforward. The host appears not to make any more fun at the expense of his dinner guests under these two signs. Therefore, it will suffice to analyse the 'astrologicality' of Trimalchio's expositions in order to further substantiate the conclusions on his scientific approach drawn so far. Furthermore, what we have here are rather clear instances of the host's awareness of the profession of the mathematicus with which he is engaging. All of these preliminary remarks equally apply to Capricorn.

in libra laniones et unguentarii et quicumque aliquid expendunt

(Sat. 39. 10)

Under the Scales, butchers, perfume-sellers and anyone who weighs things up.

Libra's influence as a measuring device on those born under it can be found in Manilius:

Librantes noctem Chelae cum tempore lucis per nova maturi post annum munera Bacchi mensurae tribuent usus ac pondera rerum (4. 203-5)

Balancing night with the length of day when after a year's space we enjoy the new vintage of the ripened grape, the Scales will bestow the employment of weights and measures

On the other hand, Trimalchio's eclectic approach erases those who are well aware of juridical questions and law in general, as described in the Astronomica (4. 209-216).

${ }^{42}$ SMITH (n. 5) 90. Cf. also Manil. 4. 190: nodoque coercita virgo, and SCHMELING (n. 5) 154: "nodes or intersecting point of the Zodiac (the autumnal equinox, Manil. 2. 176ff.), and her feet seem to be caught in it; the equinoxes and solstices are called nodes; Lucretius 5. 687-688; Manilius 3. 618-624".

${ }_{43}$ Encolpius and his comrades frequently escape at various points of the plot, not to forget from the Cena. On the fuga as literary principle in the Satyrica cf. TILG, S.: Die ,Flucht" als literarisches Prinzip in Petrons Satyrica. MD 49 (2002) 213-226. 
Similarly to those who weigh things up, these unofficial judges are born under Libra due to its natural state of being well balanced and equal:

denique, in ambiguo fuerit quodcumque locatum

et rectoris egens, diriment examina Librae. (4. 215f.)

Indeed, whatever stands in dispute and needs a ruling the pointer of the Balance will determine.

\section{Scorpio}

in scorpione venenarii et percussores (Sat. 39. 11)

Under Scorpio poisoners and murderers.

When attributing poisoners and murderers to Scorpio Trimalchio combines two prominent features of this sign as found in Manilius. On the one hand "Scorpio is the domus of the planet Mars who causes him to take on an aggressive nature", 44 on the other hand its venomous tale is one of its constituent features (acri Scorpios ictu, Manil. 2. 213; acer et ictu / Scorpios, 2. 236f.; Scorpios armata violenta cuspide cauda, 4. 127). Although Manilius does not give concrete examples of people or professions characteristic for those born under Scorpio, those Trimalchio enumerates are implied in the former author's general tendency.

\section{Sagittarius}

in sagittario strabones, qui holera spectant, lardum tollunt (Sat. 39. 11)

Under Sagittarius are born cross-eyed people who look at the vegetables and take the bacon.

Various readings have been proposed for Trimalchio's explanations under Sagittarius. One of the most convincing interpretations is put forth by Smith, ${ }^{45}$ who states "Sagittarius was associated with afflictions of the eyes, including squints (cf. Firm. Matern. viii. 27. 11 erunt unioculi, strabi), and also with thieves, i.e. men who look one way while their attention is concentrated in another direction". Yet, Smith fails to provide concrete examples from the first two centuries CE. ${ }^{46}$ Schmeling ${ }^{47}$ has come up with

${ }^{44}$ SCHMELING (n. 5) 155. Cf. Manil. 2. 443; 4. 217-229.

${ }^{45}$ SMITH (n. 5) 91

${ }^{46}$ It remains difficult to prove in how far this passage from Firmicus Maternus is based on previous astrological treatises or rather on popular beliefs of the times. Apart from the Latin translations of Aratus by Cicero and Germanicus and some astrological passages in Ovid's Fasti, Manilius' Astronomica is the only extant Latin oeuvre dealing with the science of astrology from the first centuries CE, which makes it impossible to trace back Firmicus Maternus' claim for Sagittarius in earlier works of this kind, especially if we bear in mind that it cannot be found in the first-century treatise. Moreover, only fragments from a Greek didactic poem by Anubion survive. Matters are further complicated by the fact that Firmicus Maternus never explicitly names Manilius, whom he clearly makes use of in book 4, or any other of his astrological sources. Cf. AlBrecht, M. vON: A History of Roman Literature. From Livius Andronicus to Boethius. Leiden - New York - Cologne 1997, 1610f. 
the explanation that "sagittarius closes one eye to aim his arrow", which is substantiated further by Gianotti's ${ }^{48}$ persuasive addition that in astrological representations Sagittarius is presented as a centaur with two heads facing in different directions. Moreover, his hybrid form is mentioned in the Astronomica (in bifero Centauri corpore, 4. 230; ferae mixtum est hominis per sidera corpus, 4. 238).

However, Trimalchio here omits the vast list of tasks connected with this sign: for instance, Manilius among others speaks of charioteers and huntsmen (4. 230-242; cf. also 4. 560-567). Maybe, since our main protagonists are attending a free dinner, we are meant to imagine Trimalchio pointing a finger at those who act innocently, here described as qui holera spectant, while keeping well in mind and sight what they are aiming at (lardum tollunt).

\section{Capricorn}

in capricorno aerumnosi, quibus prae mala sua cornua nascuntur

(Sat. 39. 12)

Under Capricorn, people in trouble who sprout horns through their worries.

Since Capricorn is the 'house' of Saturn, it is connected with those who endure hardships (Manil. 4. 256f.; vitae discrimen inertis, 4. 570). By contrast, the reason why prae mala sua cornua nascuntur to these people has been interpreted in various different ways. Smith ${ }^{49}$ admits, "the significance of the words prae mala sua cornua

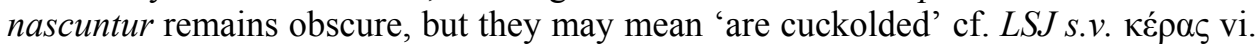
It is less likely that they refer to the Campanus morbus (cf. Hor. Sat. 1. 5. 58ff.) characterized by excrescences of the head which might resemble the scars left when horns had been removed." Equally unsatisfactory is Caiazza-Lucarini' s ${ }^{50}$ explanation of this expression as a hint at the force people born under Capricorn developed after they used to suffer a lot previously. ${ }^{51}$ Manilius, under Capricorn, speaks of professions

On the date of the Satyrica see the recent evaluation of the Petronian question by GROSSARDT, P.: Der Trojanische Krieg in der Darstellung des Trimalchio (Petron, Sat. 39, 4-5). RhM 155 (2012) 310363, at 351f.: "Die Identifizierung unseres Autors und damit die Datierung der Satyrica scheinen, nachdem die Gleichsetzung mit dem von Tacitus (ann. 16,17-20) porträtierten Hofbeamten Neros lange Zeit als nahezu unumstößlich galt, heute wieder offener denn je".

Since Terentianus Maurus quotes a passage from the Satyrica at the end of the second century, the terminus ante quem of late second-century can be firmly established and, thus, the time of composition narrowed down to the first two centuries CE. Due to strong hypertextual allusions to Lucan's Bellum Civile in Eumolpus' Bellum Civile (Sat. 119) the terminus post quem of approximately 60 CE has been widely accepted. On Petronius' allusions to Lucan's Bellum Civile cf. RosE, K. F. C.: The Date and Author of the Satyricon. Mnemosyne Suppl. 16. Leiden 1971, at 87-94.

${ }^{47}$ SCHMELING (n. 5) 155

${ }^{48}$ GiAnOtTi (n. 5) 310

49 SMITH (n. 5) 91.

${ }^{50}$ CAIAZZA-LUCARINI (n. 5) 239 f.

${ }^{51}$ CAIAZZA-LUCARINI (n. 5) 240: "un'allusione alla forza che i nati sotto il segno del Capricorno sviluppano a seguito della sofferenza". 
connected to heat, due to Vesta's tutela (4. 243-255), which Trimalchio makes no reference to.

\section{Aquarius}

in aquario copones et cucurbitae (Sat. 39.13)

Under the Water-Carrier, bartenders and judheads.

The penultimate sign is Aquarius. $\mathrm{Smith}^{52}$ is only partly right when stating that the profession of the bartender is not found associated with this sign in any astrological treatise. ${ }^{53}$ Manilius speaks of the water-pouring Aquarius and the professions connected to this task (inflexa fontem qui proicit urna, / cognatas truibuit iuvenalis Aquarius artes, 4. 259f.), and even if he does not explicitly mention the innkeeper, he indicates that it would be an enervating task to list all of these various professions connected with Aquarius (mille sub hoc habitant artes, quas temperat unda, 4. 266). As has been the case with previous signs, Trimalchio chooses to take an eclectic approach and omits those of mite genus (4. 270) as well as sanctumque [...] castumque probumque (4. 571) born under this sign according to Manilius.

The appearance of cucurbitae can be interpreted in two ways, with neither of the two being attested in Manilius: either it is understood in its meaning of 'cuppingglass for bleeding, ${ }^{54}$ or as 'judhead' or 'water on the brain'. If we want to follow the second version, what we have here is one further instance where Trimalchio ridicules Encolpius and his comrades in front of the freedmen guests of the Cena. After having designated them as voracious under Leo and having poked at the sexual orientation under Gemini, he now makes fun of their level of erudition by calling them cucurbitae. If the first option, i. e. the astrological interpretation of cucurbitae, were to be preferred, this would, in turn, substantiate Trimalchio's learned approach. However, a more fruitful reading takes the two statements together, and the hypothesis is pursued that Trimalchio aimed at leaving an ambiguous astrological construction. In this case the parodic effect at the expense of the scholastici becomes even more prominent: not only do they fail to decipher the message correctly, but by assuming that Trimalchio has the astrological meaning in mind, they are convinced that they are right, when they are not.

\section{Pisces}

in piscibus obsonatores et rhetores. (Sat. 39. 13)

Under the Fishes, fish-fryers and people who spout in public.

\footnotetext{
${ }_{53}^{52}$ SMITH (n. 5) 91.

${ }^{53}$ Moreover, he is right in seeing this passage as a pun at innkeepers, who "were often accused of putting too much water in their wine". SMITH (n. 5) 91.

${ }_{54}$ As found in Celsus 2. 9. 2; 3.18. 16, Pliny, NH. 31. 123. Cf. the detailed discussion in DE VREESE (n. 3) 192-195 and DAVIES, J. C.: Petronius, Satyricon 39,12. in aquario copones et cucurbitae. RhM 114 (1971) 288 with the addition by KEYER: Trimalchio's Astrology (n. 5) 287.
} 
The last, and probably most challenging, sign is that of Pisces. Various contributions have tried to solve the issue why Trimalchio places the rhetores under Pisces, as there is no similar or even parallel reading in any of the ancient astrological treatises. While the obsonatores have not caused further interpretative problems, ${ }^{55}$ the rhetor, whose constituent characteristics differ widely from the mute fish, does not seem to have a reason for being placed under Pisces. Yet, as with similarly intriguing passages, this one only remains obscure if it is not situated in its context and read against the general tendency of the episode.

Trimalchio opened his horoscope with one open joke at the expense of Encolpius and his comrades under Aries (scholastici, Sat. 39. 5) and equally rounds it off by one under Pisces (rhetores, Sat. 39. 13). But do we trust Trimalchio to do more than merely arrange his horoscope in the shape of a plain ring composition? Are we willing to assume that he is able to challenge the listener by hiding one further subtle last joke at the expense of his supposedly erudite guests? Having revealed such witty comments under previous signs, this interpretation appears more convincing, and indeed, many commentators agree on this matter. ${ }^{56}$

The exact nature of the joke has been vigorously debated. Agamemnon makes use of the metaphor of the rhetor fishing for students earlier in the Satyrica (3. 3-4), yet, this very passage must not be consulted when decoding the joke in Trimalchio's horoscope. Agamemnon was talking to Encolpius with Trimalchio being absent, thus, the dinner host could not have heard of this metaphor and directed it, against him who first made use of it. ${ }^{57}$ Similarly, the suggestion by Eriksson, ${ }^{58}$ following de Vreese, ${ }^{59}$ to compare cookery with rhetoric is unconvincing. Furthermore, it is equally unsatisfactory to adduce Firm. Mat. Math. 8. 30. 7, who places oratores under Pisces, since this passage from the fourth-century astrologer does not necessarily cast light and allow firm conclusions on Trimalchio's first- or second-century horoscope. Firmicus Maternus' claim may go back to earlier sources not surviving otherwise, however, this remains impossible to prove. Additionally, it cannot be found in Manilius' treatise, which Petronius clearly used as a hypotext throughout. Schmeling's ${ }^{60}$ mention that "there is a reference in Festus (p. 221 Lindsay) that obsonatores (or similar) also means convivae" seems to get closer to the point. Even though Festus does not speak of the noun obsonator, he explains the verbs obsonitavere / obsonavere from the same

${ }^{55}$ Cf. SCHMEling (n. 5) 155: "those who prepare and enjoy fish (or food in general, Seneca $E p$. 47. 8), as well as those who buy them, a proper subject under Pisces". Manilius, however, who extensively speaks of professions connected to the sea, maritime trade, ships and fishing (4. 273-291), does not explicitly speak of those who sell fish, even though this is implied (innumerae veniunt artes: vix nomina rebus / sufficiunt, 4. 277f.). Trimalchio also omits those burning with summa libido (4. 577) and garrulous people (garrulitas odiosa datur linguaeque venenum / verba maligna novas mutantis semper ad auras, 4.574f.), who are born under Pisces.

${ }_{56}$ Cf., for instance, KORENJAK (n. 5) 135.

${ }^{57}$ Cf. GiANOTTI (n. 5) 311 against SCHMELING (n. 5) 156. Against the use of the fishing metaphor for the interpretation of Pisces in Trimalchio's horoscope, cf. KORENJAK (n. 5) 135f.

${ }^{58}$ ERIKSSON (n. 4) 68f.
${ }^{59}$ DE VREESE (n. 3) 244.
${ }^{60}$ SCHMELING (n. 5) 155. 
word family. ${ }^{61}$ The most persuasive interpretation has been put forward by Korenjak, ${ }^{62}$ who rightly stresses that "Agamemnon has not uttered a single word since the beginning of the Cena" and will only speak once (65.5); and even in this single instance Trimalchio soon interrupts him. Moreover, the freedman Echion explicitly attacks the rhetor for keeping silent (Sat. 46. 1-2). He, who is supposed to speak, remains mute like a fish.

\section{WHAT TRIMALCHIO DOES AND WHAT HE DOES NOT TAKE INTO CONSIDERATION}

My discussion so far may give the impression that Trimalchio's horoscope is easy to understand when compared with and meticulously read against the relevant passages in astrological treatises of the time such as Manilius' and situated in the context of the Cena. However, as the observant reader may have already suspected, it would be surprising if Petronius were able to squeeze, for instance, five books of Astronomica into one more or less brief section without making sacrifices.

Indeed, matters are far more complicated than what the dinner host makes the listener believe. Manilius explicitly alerts the reader to the fact that various factors must be taken into consideration, while it is not enough to 'only' look at the star signs as such (2. 270-272 and 3. 548-559). Stars are related to each other in various ways and exert manifold impacts among themselves (Manil. 2. 270ff., 4. 294-362, 408416). Additionally, further factors such as their position and most influential planet at the time (2. 643-692), the dodecatemorion (2. 693-771), finally the four cardinal points $(2.788-840)$ as well as the spaces in between these $(2.841-855)$ must be included. The impact of the houses (2.856-863) and sortes (3. 47ff.), which even change position from time to time (3. 165-167), is particularly important. On these grounds, it is vital to first calculate the position of Fortuna among the star signs at the time of birth, before moving on to the other factors mentioned above (3. 169-172). ${ }^{63}$ Therefore, people who are born under the same star sign may show fully different character traits (Per tot signorum species contraria surgent / corpora totque modis totiens inimica creantur; 2. 579f., see also 2. 707-712 and 4. 370-386).

As can be seen in section V, Trimalchio does not include most of these factors and presents an overly simplified horoscope. The question whether or not he is aware of this has been hinted at several times, yet remained open thus far. At first sight it may seem that he only remembered certain bits of astrological discourse; this claim stands in line with the commonly held scholarly view of Trimalchio as pretentious pseudointellectual. However, there are some instances where the dinner host proves to have

\footnotetext{
${ }^{61}$ Festus (De verborum significatione p. 221 Lindsay): obsonitavere] saepe obsonavere. significat autem convivari.

${ }_{62}^{62}$ KorenJaK (n. 5) 137.

${ }^{63}$ The procedure for calculation is explained in detail at 3. 176-519.
} 
further knowledge: he demonstrates this, for instance, under Taurus by recalling the representation of the star sign, under Cancer with the tutela of Mercury, and under Capricorn with the impact of the planet Saturn, which is to be treated separately from the watching god, i. e. Vesta. It is, then, not unjustified to conclude that Trimalchio is aware of the complexity of the matter, yet deliberately chooses to present this eclectic brief version. After all, it becomes apparent that he tries to entertain his guests and to show off his erudition. Only by presenting a simplistic horoscope, which is consciously semi-based on scientific astrological knowledge of the time, can he achieve both. ${ }^{64}$

This, in turn, highly questions the overall picture of the nouveau riche Trimalchio Petronian scholars have widely drawn. ${ }^{65}$ If the host is able to give a deliberately semi-scientific astrological horoscope and, furthermore, to enrich this with subtle jokes at some of the attendant guests, his claim for learnedness even when dining (oportet etiam inter cenandum philologiam nosse, Sat. 39. 3) seems not to be far-fetched. It would go far beyond the scope of this contribution to elaborate further on the idea of regarding Trimalchio as a witty host. ${ }^{66}$ This would require a thorough discussion of several other instances in the Cena where he infringes, for instance, canonical versions of myths (for example Sat. 48 and 53), as well as the possible reasons for this behaviour. I shall therefore confine myself to questioning the compromising and pejorative image, which Petronian scholarship has commonly drawn of Trimalchio.

\section{CONCLUSION}

The dinner host is made to choose an eclectic and deliberately semi-scientific approach when compiling and expressing his horoscope, making use of astrological material from scientific discourse. Petronius the author draws his protagonist's claims close to those found in Manilius and at times visualises what may only be implied in the $A s$ tronomica. Moreover, he has Trimalchio deliberately undertake an overly simplistic approach leaving out a large part of constituent factors. Nonetheless, the freedman at times makes clear that he is aware of the complexity of the underlying science of astrology. By inserting frequent jokes at the expense of his uninvited, supposedly 'erudite' guests Agamemnon, Encolpius, Ascyltus, and Giton, he is not only able to entertain his fellow freedmen guests but also to unmask the hollowness of the scholastici et rhetores. As becomes apparent twice (Sat. 39. 6 and 40. 1), those who should see through the host's jokes at their own expense do not. On the contrary, they seem even to be genuinely amused.

${ }^{64}$ Presenting a fully astrological horoscope which takes into consideration all of the factors mentioned above and explained in Manilius would most likely bore the dinner guests to death, whereas compiling a lecture that is fully fictive and far from any scientific knowledge would expose Trimalchio as hollow comic relief.

${ }^{65}$ As mentioned in the introductory chapter, DE VREESE's (n. 3) interpretation implies a different, i.e. smart, Trimalchio. As far as I can see, he is the exception to the rule of regarding the host as a pseudointellectual, who, instead of displaying his erudition, constantly unmasks his ignorance.

${ }^{66}$ Cf. Rimell, V.: Petronius and the Anatomy of Fiction. Cambridge 2002, at 46f. 
There is no indication that Petronius ridicules the non-scientific approach Trimalchio or ancient astrologers such as Manilius in general undertook. ${ }^{67}$ This interpretation would imply that ancient writers were aware of the dichotomy scientific vs. popular to such an extent that the latter would have to be dismissed. Any approach by today's reader must be subject to renewed vigilance: modern theoretical and methodological considerations must not be neglected in these regards.

On an authorial level the author Petronius is able to expose these protagonists even further by having the older Encolpius narrate these events without displaying any change in attitude to his former self's reactions. He may have grown older, however, he is still not able to interpret the freedman's urbanitas in the right terms. It appears likely that even the external recipient may have been struggling to rightly locate Trimalchio's horoscope within the continuum of amateur astrology and erudite gimmick.

Oliver Schwazer

University College London

United Kingdom

oliver.schwazer.12@ucl.ac.uk

${ }^{67}$ Cf. ERIKSSON (n. 4) 53: "Meiner Ansicht nach ist es unverkennbar, dass Petron hierdurch nicht nur die Unkenntnis Trimalchios vom Indikator und von der Methode, sondern auch das Lächerliche und Sinnlose in dieser einfachen und zu jener Zeit sicher allgemein praktizierenden Methode hervorheben will" and 75: "Petron greift mit den Waffen der Ironie die zentrale und uralte Deutungsmethode der Astrologie an." 